\title{
The interplay of entrepreneurial and non-entrepreneurial internationalization: an illustrative case of an Italian SME
}

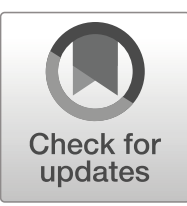

\author{
Niina Nummela ${ }^{1}$ (D) Tiia Vissak $^{2}$ (D) Barbara Francioni $^{3}$ (D)
}

Published online: 29 May 2020

(C) Springer Science+Business Media, LLC, part of Springer Nature 2020

\begin{abstract}
This study describes SME internationalization as a process that combines entrepreneurial and non-entrepreneurial behaviour. We bring in insights from prior literature and use an illustrative case study of an Italian SME to demonstrate the interplay of entrepreneurial and non-entrepreneurial behaviour during the internationalization process. Our study shows that the combination of entrepreneurial and nonentrepreneurial internationalization cannot be fully explained with existing International Entrepreneurship literature or other internationalization theories, as they do not take into account the nonlinear nature of internationalization or explain why the process seems to reach a 'glass ceiling' beyond which it does not progress. The study concludes with a conceptual framework providing an alternative explanation. Based on our conceptual reasoning we propose that predominantly nonentrepreneurial internationalization can occur without developing a clearly defined internationalization strategy. Additionally, we argue that low commitment to internationalization prevents capability development and may lead to nonlinear internationalization. Furthermore, we suggest that family involvement may moderate a firm's international entrepreneurial orientation, consequently leading to more nonentrepreneurial internationalization.
\end{abstract}

Keywords Internationalization - Entrepreneurial internationalization $\cdot$ Nonentrepreneurial internationalization - International entrepreneurship · SME · Case study . Family firm

\footnotetext{
Tiia Vissak

tiia.vissak@ut.ee

Niina Nummela

niina.nummela@utu.fi

Barbara Francioni

barbara.francioni@uniurb.it
}

Extended author information available on the last page of the article 


\section{Introduction}

During the last 30 years, a new research field - International Entrepreneurship (IE) ${ }^{1}-$ has emerged at the intersection of Entrepreneurship and International Business (IB). IE scholars have predominantly focused on entrepreneurs who identify and exploit opportunities across national borders and on firms that enter global markets as quickly as possible (Jones et al. 2011). These global start-ups (Oviatt and McDougall 1994) are growing fast, but they form a minority among internationally active SMEs. Most firms internationalize slowly, and for many international operations - even if they have continued for years - remain less important than domestic activities (Vissak and Masso 2015).

Entrepreneurial internationalization ${ }^{2}$ is in the "centre" of IE (Jones et al. 2011) and, increasingly, IB research (Buckley and Casson 2020; Christmann et al. 2016). In prior research, the term has been understood very broadly. For example, Lumpkin and Dess $(1996,136)$ stated that a new entry to a new market is "the essential act of entrepreneurship", and recently Alayo et al. (2019) strengthened the argument by explaining that internationalization as an entrepreneurial act combines identifying and exploiting new business opportunities in new markets with risk acceptance and ability to innovate. Not surprisingly, internationalization has been also associated with entrepreneurial orientation (Slevin and Terjesen 2011; Jones and Coviello 2005): i.e., bold, opportunity-seeking behaviour characterized by innovativeness, risk taking and proactiveness (Dess et al. 1997). Accordingly, we define entrepreneurial internationalization as a process characterized by innovative, proactive and risk-seeking activities across national borders.

Whether the behaviour of all internationalizing SMEs meets the above description, is another question. Interestingly, some studies describe internationalizing SMEs as non-entrepreneurial and conservative, and their management style as non-innovative, risk-averse, and passive or reactive (Covin and Slevin 1988; Lazaris et al. 2015; Reuber et al. 2017). Such internationalization is particularly common among some family firms which are more focused on non-economic goals (such as retaining their socioemotional wealth $^{3}$ ) than on economic goals, including growth and profit maximization. These firms are quite cautious in expanding internationally as that could result in decreasing control over the firm due to the potential need of involving outside investors or managers (Metsola et al. 2020; Pukall and Calabrò 2014). Thus, although entrepreneurial internationalization could occur in any industry or context (Jones and Coviello 2005) and "in all types of companies, regardless of age or size" (Baier-Fuentes et al. 2019, 386), it does not always happen. Furthermore, SMEs' entrepreneurial orientation varies, and the dimensions of entrepreneurial orientation are not always present at the

\footnotetext{
${ }^{1}$ It is understood as "the discovery, enactment, evaluation, and exploitation of opportunities - across national borders - to create future goods and services" (Oviatt and McDougall 2005, 540).

${ }^{2}$ Researchers' views and definitions on entrepreneurial internationalization vary. For example, for Amorós et al. $(2016,286)$ entrepreneurial internationalization equals "entrepreneurs' early internationalization". Torkkeli et al. (2019) studied SMEs' internationalization and called it "entrepreneurial internationalization". Etemad (2018), Hagen et al. (2019) and Sedziniauskiene et al. (2019), without clearly defining this concept, hinted that they meant born globals' and international new ventures' early internationalization, while Kahiya (2020) covered all firms' internationalization.

${ }^{3}$ Socioemotional wealth has been defined as a combination of family continuity, prominence (e.g. reputation, recognition and social relationships) and enrichment (Debicki et al. 2016; Llanos-Contreras et al. 2019).
} 
same time (Randerson 2016). Consequently, we assume that internationalization of SMEs can have both entrepreneurial and non-entrepreneurial characteristics.

We argue that contrary to strategic entrepreneurial internationalization: i.e., purposeful entrepreneurial - proactive, innovative, sustainable (Autio 2017) and risk-taking (Kuivalainen et al. 2012) or -seeking (Jones and Coviello 2005) action - some SMEs' internationalization is predominantly non-entrepreneurial: opportunistic, sporadic and discontinuous (Bernini et al. 2016). Their international activities are often nonlinear as their international commitment varies over time (Vissak and Francioni 2013; Vissak et al. 2020). Furthermore, their international growth is limited: it seems to have a boundary that is difficult to overcome. After internationalizing incrementally for quite some time, they seem to hit a 'glass ceiling'; i.e. a maximum level of commitment to international operations, which they cannot exceed.

In this study we are interested in how SMEs combine entrepreneurial and nonentrepreneurial elements in their internationalization and why? Prior International Business (IB) or International Entrepreneurship (IE) research does not answer this question. Since the 1970s, three main theories have dominated IB research: the OLI framework (Dunning 1973, 1977, 2000), internalization theory (Buckley and Casson 1976, 1998, 2020; Rugman and Verbeke 2003) and the internationalization process of the firm (Johanson and Vahlne 1977, 2009; Vahlne and Johanson 2017). They have investigated the same phenomenon from different perspectives: OLI framework explaining why and where firms expand overseas (especially, why they invest), internalization theory rationalizing the most efficient organization form to expand, and the internationalization process theory clarifying how firms enter international markets (Santangelo and Meyer 2017). ${ }^{4}$ None of them explains why firms would combine entrepreneurial and non-entrepreneurial elements in their internationalization. The Uppsala models (the original and later revisions) capture the incremental internationalization process but do not explain the nonlinear nature of the process, or the fact that commitment to internationalization sometimes remains low. On the other hand, in the IE literature the focus has been on the earliness and speed of internationalization, with a strong underlying assumption of entrepreneurial behaviour and practically excluding the potential non-entrepreneurial elements in the process.

Our study offers a deeper understanding of the interplay of non-entrepreneurial and entrepreneurial behaviour in internationalization. It builds on a literature review encompassing insights from both IB and IE research, and analyses an illustrative case of an Italian exporter. The case highlights the complexity of family-owned SMEs' internationalization process and challenges in studying them. The combination of literature-based discussion and an empirical case allows us to propose an alternative explanation for SME internationalization - a conceptual framework for future research. Additionally, it brings forward a group of firms that are significant in terms of numbers but have so far been marginalized in earlier research.

\footnotetext{
${ }^{4}$ Additionally, especially since the $1990 \mathrm{~s}$, many authors have attempted to explain the emergence of born globals, international new ventures and other accelerated internationalizers (Dzikowski 2018; HurmerintaPeltomäki 2003; Knight and Cavusgil 1996; Kuivalainen et al. 2012; Øyna and Alon 2018; Romanello and Chiarvesio 2019; Rialp-Criado et al. 2010).
} 


\section{Literature review}

Key decision-makers - entrepreneur(s) and/or top manager(s) affect firms' internationalization considerably (Francioni et al. 2013; Jones and Coviello 2005; Lazaris et al. 2015; Morais and Ferreira 2020). Their international or global mindset (Andresen and Bergdolt 2017; Torkkeli et al. 2018), experience, background, networks (Bembom and Schwens 2018) and strategic orientations (Jantunen et al. 2008; Rialp-Criado et al. 2010) can steer firms' international growth. On the other hand, not all entrepreneurs want to grow their firms (Nummela et al. 2005), and without commitment to internationalization it never happens (Calabrò et al. 2017; Francioni et al. 2013; Tabares et al. 2020). The situation is particularly complex in family firms with diverse aspirations of growth among the family members, which is reflected in their internationalization (Arregle et al. 2017).

According to some authors, exporting SMEs are more innovative, proactive, risktaking (O'Cass and Weerawardena 2009) and growth-oriented (Magnani and Zucchella 2019) than non-exporters. Moreover, they - especially, early internationalizers (Jones and Coviello 2005) - are flexible and responsive to customers' changing needs (Hagen et al. 2019): thus, they are entrepreneurial. However, all behaviour related to exports is not entrepreneurial: international activities can also be based on previously developed routines (Balabanis and Spyropoulou 2007; Zahra et al. 2005) ${ }^{5}$ or unsolicited orders (Acedo and Galán 2011; Ciravegna et al. 2019; Hennart 2014) or they can be driven by external agents (Welch 2004). Thus, many firms "pursue international opportunities in ways that do not require the highly innovative behavior and risk-taking attitudes" (Reuber et al. 2017, 418). Moreover, some of them - especially family firms (Metsola et al. 2020; Pukall and Calabrò 2014) - "are conservative, risk-averse, and reluctant to change" (Alayo et al. 2019, 49); thus, they can be considered nonentrepreneurial. ${ }^{6}$

Researchers' understanding on what is entrepreneurial internationalization varies. Tiessen and Merrilees (1999) emphasized that firms should constantly search for and create innovative product-market combinations and Tang et al. (2009, 197) stated: "Entrepreneurial firms should set proactive goals that may appear to be bold in nature". On the other hand, according to Lumpkin and Dess (1996), entrepreneurial acts do not always require simultaneous innovativeness, proactiveness and risk-taking. Moreover, Balabanis and Spyropoulou (2007) concluded that firms' approaches to developing export strategies vary from formal planning to opportunistic market response. Thus, instead of classifying SMEs' internationalization dichotomously into entrepreneurial and non-entrepreneurial, we assume that internationalizing SMEs combine both entrepreneurial and non-entrepreneurial behaviour and therefore their degree of entrepreneurial internationalization varies.

Prior research helps us to understand entrepreneurial internationalization and its antecedents, but gives us a limited view of non-entrepreneurial internationalization. In this study, we assume that it is characterized by critical events leading to 'epochs' of

\footnotetext{
${ }^{5}$ being a "mere replication in the sense of "doing more of the same" (Verbeke and Ciravegna 2018, 392).

${ }^{6}$ Of course, this does not apply for all family firms: for instance, Pascucci and Bartoloni $(2018,550)$ mentioned that one of their studied entrepreneurs had "'global mindset', with a strong international orientation". Moreover, according to Arregle et al. (2017), family firms' exports do not differ significantly from nonfamily firms' exports.
} 
internationalization which occur at different speed (Bell et al. 2001; Kutschker et al. 1997). Over time, this reactive internationalization process can become more complicated (Acedo and Galán 2011), and such internationalization is less likely to result in long-term, substantial international presence (De Clercq et al. 2005). Nonlinear internationalization seems to be particularly common among SMEs (Lloyd-Reason and Mughan 2002), and in the initial phases of internationalization (Lu and Beamish 2001). This is not surprising, as many SMEs respond to international opportunities as they rise, instead of taking a more strategic approach (Love and Ganotakis 2013) or planning in advance (Crick and Crick 2014; Crick and Spence 2005; Lazaris et al. 2015).

In terms of (non-)entrepreneurial internationalization and export success, the findings from previous research are mixed. According to Jin et al. (2018), successful internationalizers' levels of proactiveness, innovativeness, and risk-taking differ considerably but risk-taking entrepreneurs expand to more countries and achieve better financial performance. According to Balabanis and Spyropoulou (2007), entrepreneurial internationalization is especially successful if markets are hostile, dynamic and heterogeneous. On the other hand, Sundqvist et al. (2012) stated that in case of relatively stable markets, managers should be competitively more aggressive and very proactive but less innovative, risk-taking and autonomous, whereas on very dynamic markets, do the opposite.

In sum, prior research offers us limited information about the interplay of nonentrepreneurial and entrepreneurial behaviour in internationalization. Discussion seems to focus on either firms that internationalize by incrementally increasing their commitment to international markets (indefinitely), or firms that internationalize rapidly to global markets. Neither of the approaches discusses in detail the (non-) entrepreneurial characteristics of the process. With an illustrative case study of an Italian SME we portray the interplay of entrepreneurial and non-entrepreneurial behaviour during the internationalization process.

\section{Research design}

Qualitative research has great potential in uncovering interesting and unexpected phenomena, which are often overlooked in large-scale quantitative studies with statistical analysis (Helfat 2007). In particular, case studies are useful when current theories inadequately explain the investigated phenomenon (Eisenhardt 1989), such as the interplay of entrepreneurial and non-entrepreneurial internationalization. Moreover, they allow responding to how and why questions in process research (Leonard-Barton 1990); a relevant aspect in this study. We chose case study as our research strategy: i.e., we studied the history of the focal phenomenon with multiple sources of evidence (systematic series of interviews, observation, public and private archives) in its naturalistic context (Leonard-Barton 1990; Piekkari et al. 2009). Thus, we were able to produce contextualized knowledge, which has been called for in International Business research (Welch et al. 2011).

Our longitudinal, real time study is based on a single case. We agree with Siggelkow (2007) that a single case can be very powerful, particularly in refining existing theories (Tsang 2014). Even if current theories are well-received, a single case can be useful to elucidate aspects of theory which have been previously ignored or caught less attention 
(Easton 2010). Our illustrative case is a 'classic case study' (Dyer Jr and Wilkins 1991), i.e., a rich description of the internationalization process of the case firm, and the context and drivers of changes in its internationalization. The longitudinal, real-time data collection of the case allows us to track for the sequence and nature of internationalization-related events as well as cause and effect; thus, increasing the internal validity of our study (Leonard-Barton 1990). Our holistic case study is also unique as we were fortunate to have a prolonged open access to the case firm which provided us a distinctive setting in which to observe the internationalization process of the firm. ${ }^{7}$ The result is an in-depth case, which produces deep understanding of the interplay of entrepreneurial and non-entrepreneurial internationalization of an SME (see Fletcher and Plakoyiannaki 2011) and thus can be described as a critical case as it "permits logical generalization and maximum application of information to other, highly similar cases" (Patton 2015, 266).

Our case firm Di.Bi. is a small Italian producer of doors and security shutters for windows founded in 1976 (see Appendix Table 6). We collected retrospective longitudinal data of its exports (see Tables 1, 2 and 3 and Fig. 1) and interviewed its key decision-makers in 2015-2020. The interviews were conducted in Italian, tape-recorded, transcribed (verbatim), and translated from Italian to English by the interviewing co-author Barbara Francioni within a week after each interview. Additionally, the findings from interviews were triangulated with other data sources (see Table 4).

Based on our empirical evidence, we compiled a 'thick description' (Geertz 1973) of the case. First, we prepared a primary narrative from the raw data (Eisenhardt 1989): simplified, abstracted and transformed the data by writing summaries and coding. In the analysis we utilized systematic combining, grounded in abductive logic where the "theoretical framework, empirical fieldwork, and case analysis evolve simultaneously" (see Dubois and Gadde 2002, 554). The case analysis affected our theoretical thinking, which in turn influenced the empirical investigation (see Järvensivu and Törnroos 2010). To capture the process, we applied data-driven temporal bracketing strategy: decomposed the data in successive periods based on critical events (see Langley 1999), i.e., international market entry epochs.

\section{Di.Bi.'s internationalization}

\section{The 1990s - Agent-driven internationalization}

In 1976-1990, Di.Bi. focused on the Italian market. In 1991, through a personal contact (an Italian living in Bulgaria) it started exporting to Bulgaria. The entrepreneur has tried to support exports by visiting the country, attending trade fairs and conducting market research, but customer relationships have remained inconsistent. In 2009, Di.Bi. did not export to Bulgaria due to the economic crisis. In 2016, exports increased substantially due to a large project delivery, but in 2018 , sales decreased considerably due to reduced orders.

\footnotetext{
${ }_{7}^{7}$ De Massis and Kotlar (2014) and Metsola et al. (2020) encouraged such an approach for studying family businesses.
} 


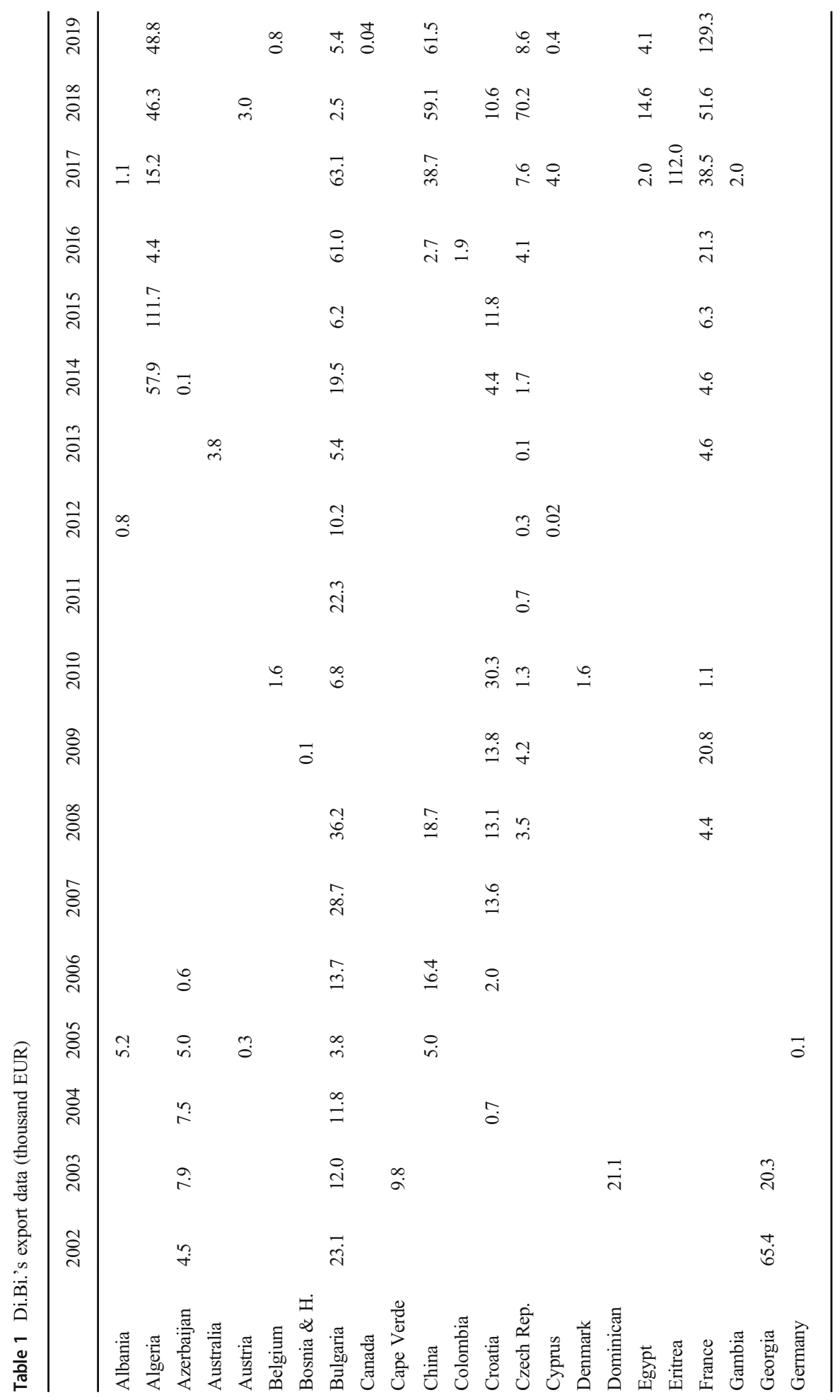




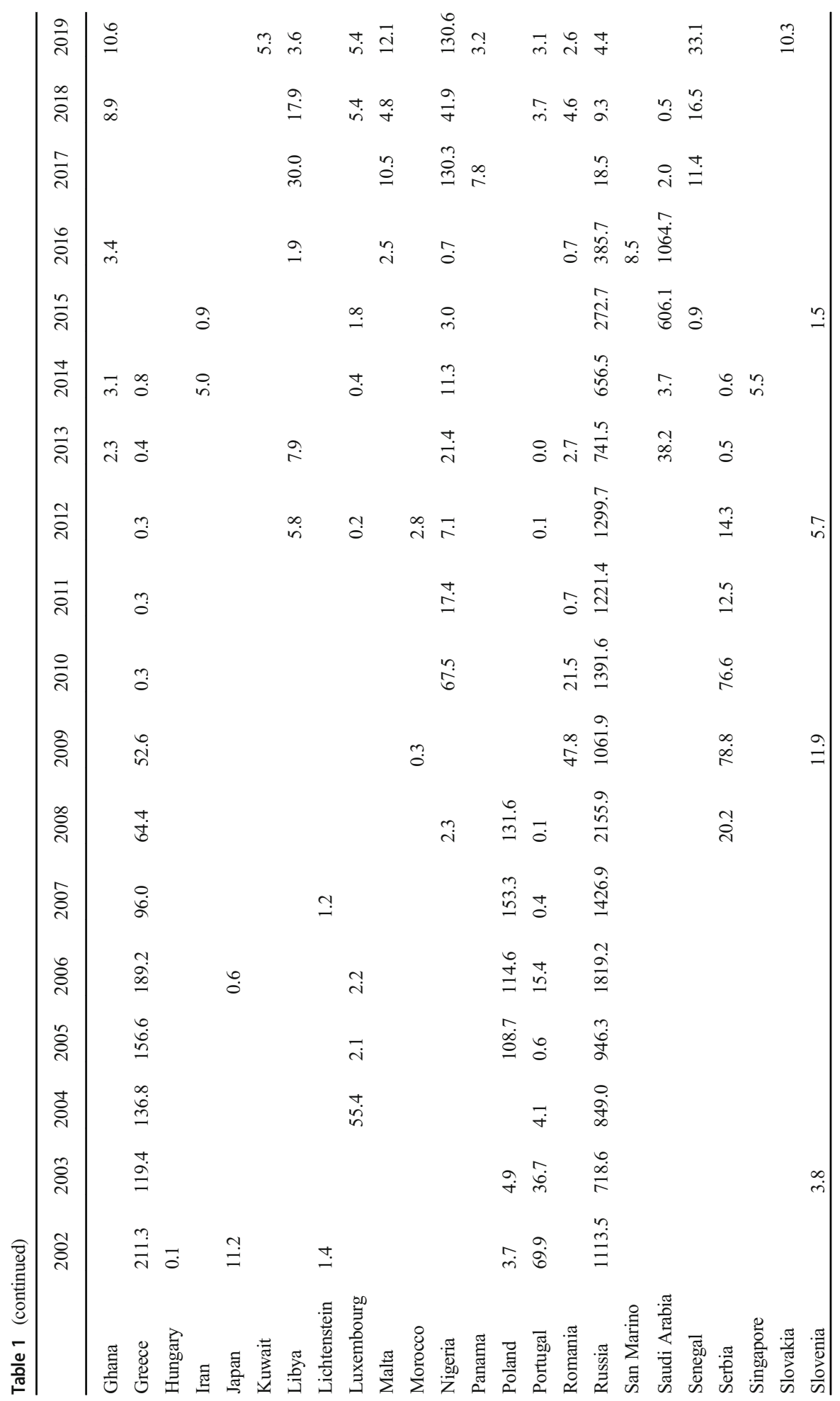




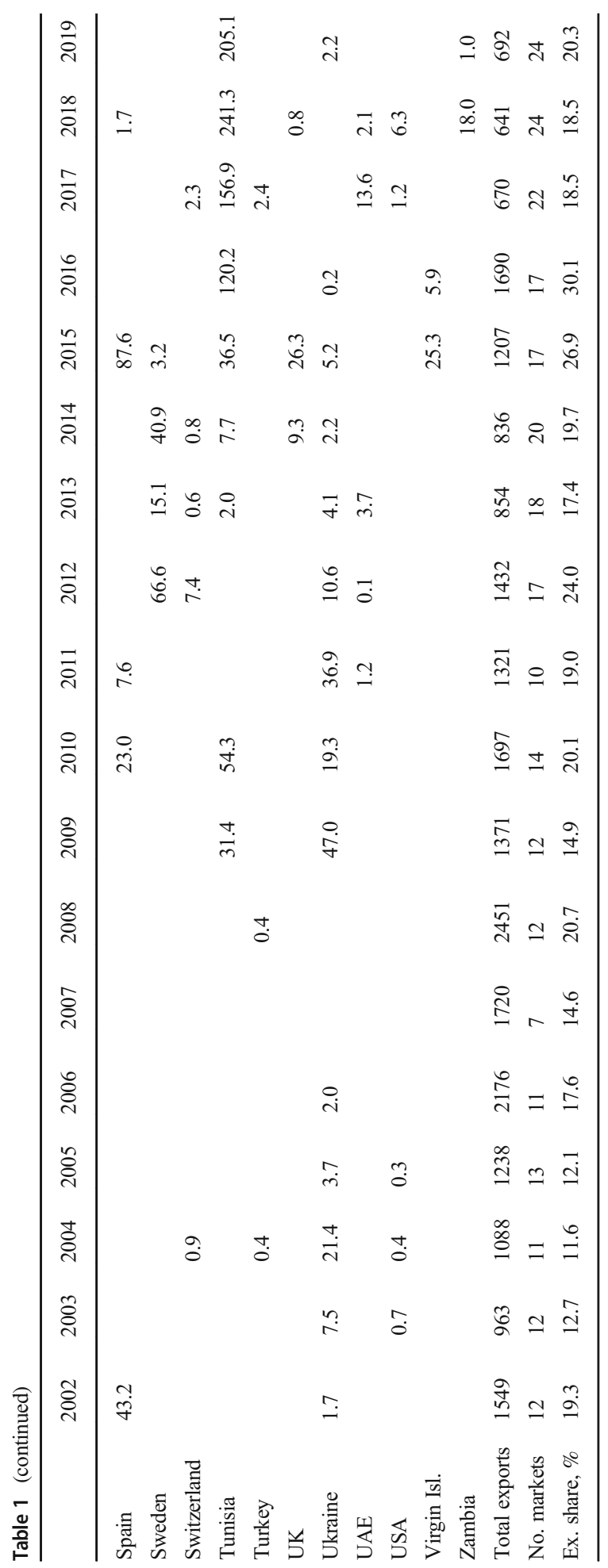




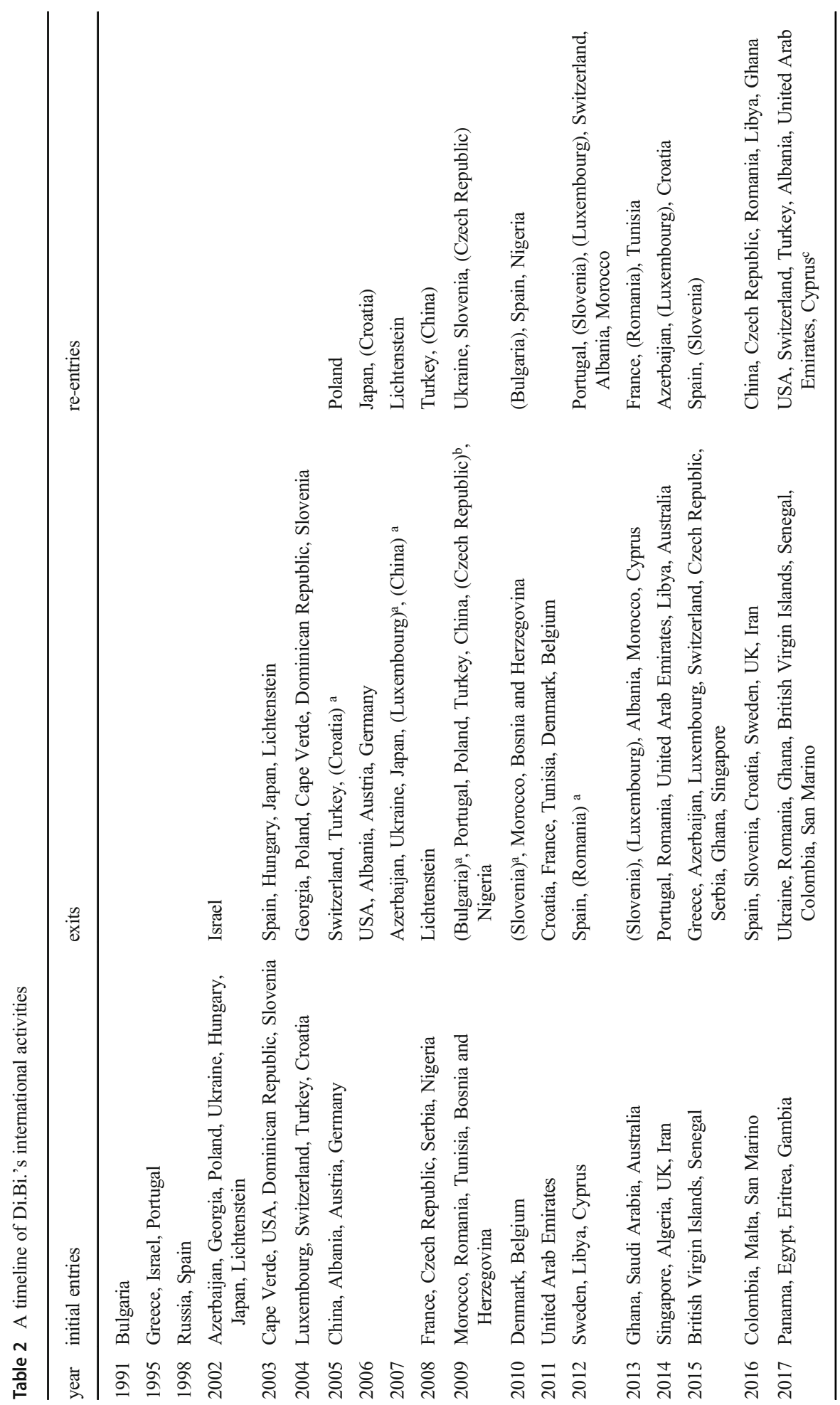




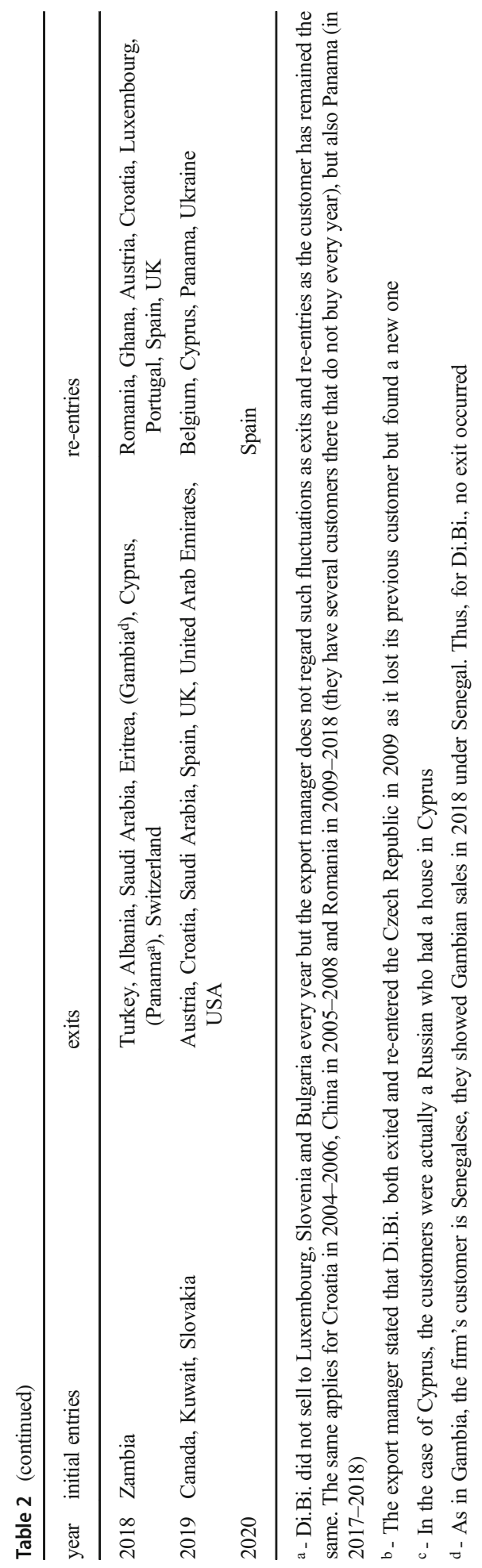


Table 3 Factors affecting Di.Bi.'s international activities by countries

initial entry

- the firm found a new customer

- a personal or business contact

- an agent

- a local customer with a foreign project

- an unsolicited export order (for instance, after visiting the firm's website)

exit

- orders stopped

- it was a single order

- problems with an agent

- the economic crisis

- strict construction requirements (the firm lacked a specific fire resistance certificate)

- the firm's price was too high

- inability to visit the country due to CD's maternity leave

- low demand

- war

re-entry

- orders for spare parts

- a new agent

- unsolicited export order

- the firm found a new customer

- the previous customer ordered again

- an order after a trade fair

- a local customer with a foreign project
Czech Republic, Serbia, Libya, Saudi Arabia, UK, Senegal

Bulgaria, Tunisia, Sweden, Ghana, Algeria, British Virgin Islands, Malta, Panama, Egypt, Eritrea, Gambia, Zambia

Greece, Israel, Portugal, Russia, Spain, Azerbaijan, Georgia, Poland, Ukraine, Cape Verde, USA, China, Albania, Austria, Morocco, Denmark, Singapore, Colombia, San Marino

Dominican Republic, Luxembourg, France, Romania

Hungary, Japan, Lichtenstein, Slovenia, Switzerland, Turkey, Croatia, Germany, Nigeria, Bosnia and Herzegovina, Belgium, United Arab Emirates, Cyprus, Australia, Iran, Canada, Kuwait, Slovakia

Greece, Portugal, Azerbaijan, Poland, Ukraine, Slovenia, Luxembourg, Croatia, China, France, Czech Republic, Romania, United Arab Emirates, Sweden, Ghana, Saudi Arabia, UK, Iran, British Virgin Islands, Senegal, Spain, USA

Hungary, Japan, Lichtenstein, Dominican Republic, Slovenia, Switzerland, Turkey, Albania, Germany, Czech Republic, Nigeria, Morocco, Bosnia and Herzegovina, Belgium, Cyprus, Australia, Singapore, Eritrea, Gambia, Panama, Austria, Croatia

Israel, Spain, Azerbaijan, Georgia, Poland, Ukraine, Cape Verde, USA, China, Albania, Austria, Morocco, Denmark, Colombia

Portugal, Spain

Japan, Slovenia, Switzerland, Croatia

Czech Republic, Serbia, Romania, Tunisia

Tunisia

Denmark

Libya

Portugal, Azerbaijan, UK, Cyprus

Spain, USA, Morocco, Romania, Ghana

Spain, Poland, Japan, Lichtenstein, Switzerland, Turkey, Cyprus, Senegal, USA, Portugal, Austria, Romania, Spain, Belgium, Spain

Ukraine, Slovenia, Croatia, China, Albania, France, Czech Republic, Nigeria, Romania, Tunisia, United Arab Emirates, Ghana, Austria, Croatia, Luxembourg

Switzerland, France, Panama, Ukraine

Turkey, Romania

Czech Republic

Croatia 
Table 3 (continued)

\begin{tabular}{|c|c|}
\hline \multicolumn{2}{|l|}{$\begin{array}{l}\text { - the country's fire resistance requirements } \\
\text { changed }\end{array}$} \\
\hline - a personal or business contact & Libya, Luxembourg \\
\hline \multicolumn{2}{|l|}{ (temporary) export fluctuation } \\
\hline $\begin{array}{l}\text { - fluctuating orders from the only or a major } \\
\text { customer }\end{array}$ & $\begin{array}{l}\text { Russia, Spain, Slovenia, Luxembourg, France, Serbia, } \\
\text { Nigeria, Tunisia, United Arab Emirates, Sweden, Saudi } \\
\text { Arabia, Bulgaria, the Czech Republic }\end{array}$ \\
\hline - high competition & Russia, Slovenia, Serbia \\
\hline $\begin{array}{l}\text { - some sales were in statistics under another } \\
\text { country }\end{array}$ & Russia, British Virgin Islands \\
\hline - the economic crisis & Bulgaria, Russia \\
\hline - a small market & Slovenia, Luxembourg \\
\hline - the country increased import tariffs & Algeria \\
\hline - the firm's price was too high & Algeria \\
\hline - the firm found a new customer & Algeria \\
\hline - the agent became less active & Greece \\
\hline
\end{tabular}

In 1995, the owner started co-operating with an Italian export agent. Through this agent, Di.Bi. entered Israel, Greece and Portugal and later several other countries. In 2002, it withdrew from Israel due to lack of customers. During the 1990s, Greece was one of Di.Bi.'s most important markets. As the agent was not very active there, in 2008 Di.Bi. started exporting directly. ${ }^{8}$ Due to the economic downturn in 2007-2009, business in Greece and Portugal decreased; Di.Bi. exited Greece in 2015 while sales to Portugal have remained inconsistent, mainly relying on occasional orders.

Collaboration with the same agent continued on new markets: in 1998, Di.Bi. entered Spain and Russia. The Spanish market seemed promising, but orders decreased and in 2003, Di.Bi. withdrew. In 2010, it re-entered the market through a Spanish agent, but collaboration failed soon. Moderate direct exports to one customer continued until 2015, when collaboration with a new agent started, and decreased again due to the agent's health problems. Still, sales to Spain were occasionally high due to non-recurring deals with non-Spanish customers who needed doors in Spain. After finding a new agent in Spain, Di.Bi. made a small sale in 2018 after receiving an order from an architect; no more orders came in 2019 but small sales continued in 2020 .

In Russia, the Italian agent's efforts led to an exclusive distribution agreement with a major customer who assembled Di.Bi.'s products and sold hundreds of doors monthly in 25 stores. However, orders diminished due to the distributor's financial problems. The export manager Caterina Delvecchio (CD) tried to contact potential customers directly, but failed. Gradually business decreased, both due to introduced tariffs and due to changed market situation. CD described the competition in Russia as "ruthless" and

\footnotetext{
${ }^{8}$ An export department was established in 2008 and Caterina Delvecchio became the export manager.
} 


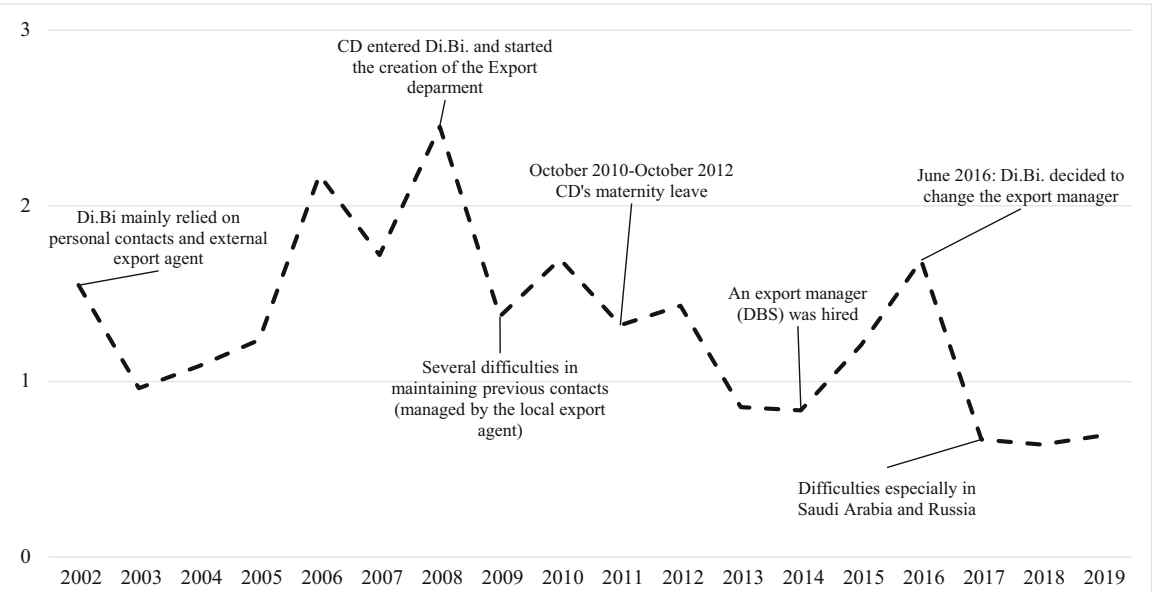

Fig. 1 Di.Bi.'s exports, million EUR

the overall situation as "continuity of state of crisis". She also complained that it is hard to find Italian or even English speakers in Russia.

\section{The 2000s - Haphazard internationalization}

During this period, Di.Bi. continued exports via the agent and exported directly to many international markets, but mostly temporarily. For example, in 2002, the Italian agent assisted Di.Bi. in entering Poland, Ukraine, Azerbaijan and Georgia. None of these markets generated stable sales, despite CD's efforts. Local competition, especially in the low-cost segment, was strong and the social and political problems in Azerbaijan and Georgia did not make business easier. In 2002, Di.Bi. also received an unsolicited order from Japan but, thereafter, left the market. CD considers Japan's strict construction requirements very challenging, and thus she has not tried to re-enter it.

In the 2000s, Di.Bi. entered many mostly smaller markets (Albania, Bosnia and Herzegovina, Cape Verde, Dominican Republic, Hungary, Liechtenstein, Luxembourg, Morocco, Romania, Serbia, Singapore, Slovenia, Switzerland), but orders remained occasional. Often the main reason was strong competition, especially in the lower price segments. For example, according to $\mathrm{CD}$, Romanian customers "generally buy where they find the cheapest price, in an extremely opportunistic way."

USA looked initially more promising, but no orders came in 2006-2016. Re-entry was difficult: CD searched for potential customers and even gave a student assignment - market research - to American students studying in Italy, but without promising results. Di.Bi. also found a new agent (an Italian who moved to the USA) and tried piggybacking with an Italian kitchen producer. However, in 2019, no new orders came from the US.

In 2004, Di.Bi. started exporting to Croatia through a local distributor. However, collaboration ended because Di.Bi.'s products lacked a fire resistance certificate. Di.Bi found another customer in 2014 when Croatia adopted the European standard but this customer only ordered once. In 2018, it re-entered Croatia again after finding a new customer but $\mathrm{CD}$ was pessimistic about future sales, suspecting: "Probably he used us 


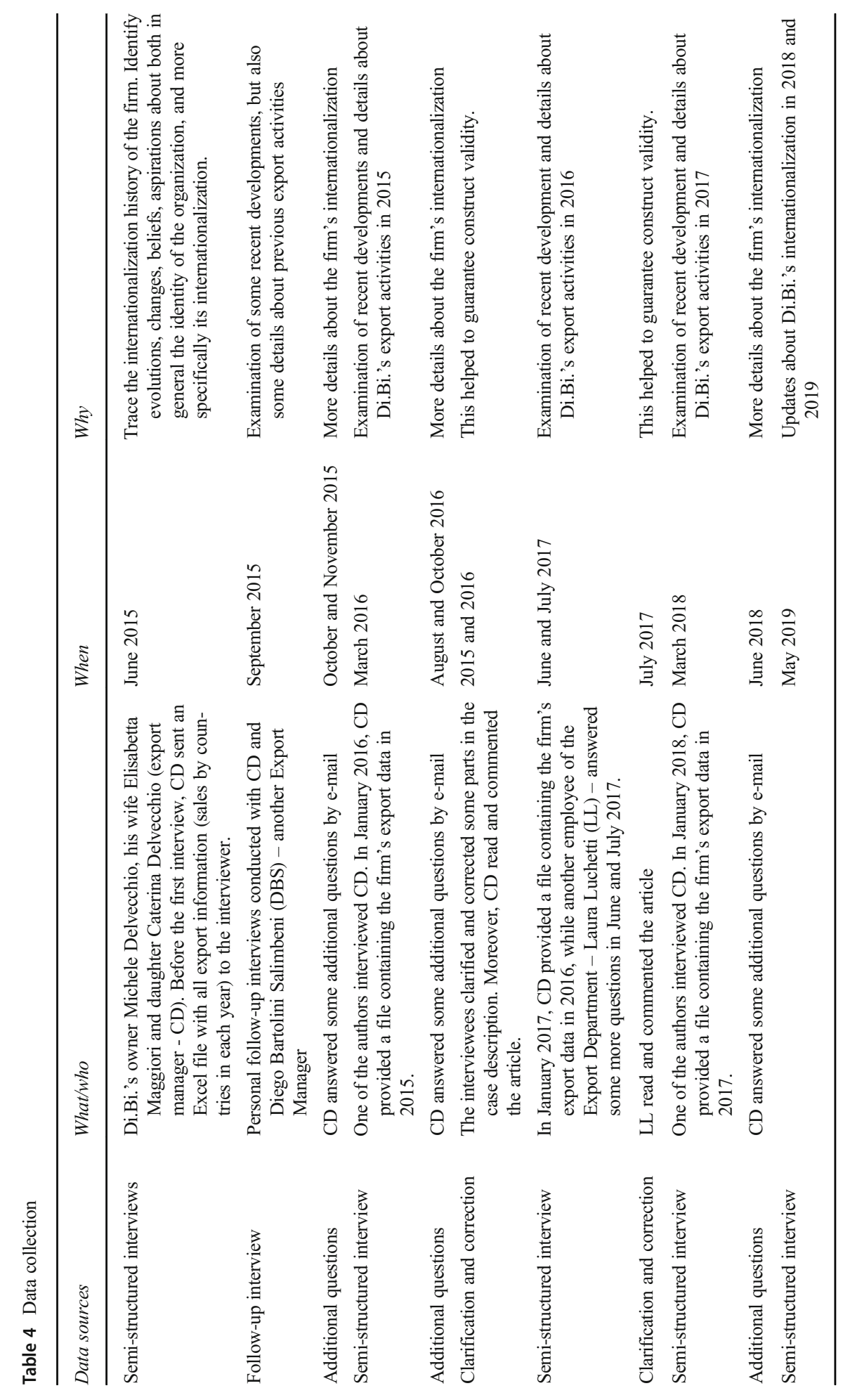




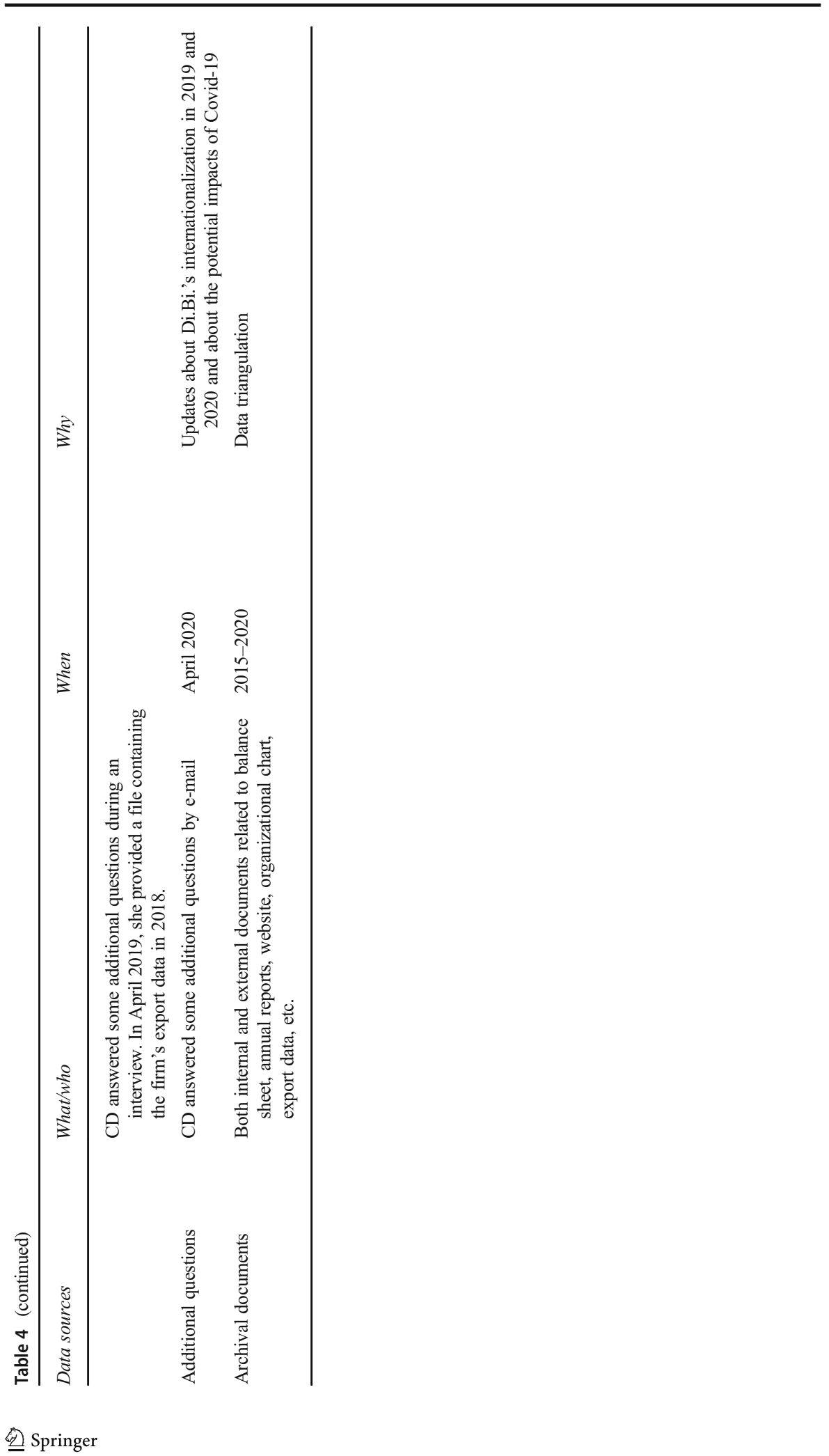


for obtaining lower prices from our competitor". She was right: in 2019, no orders followed. In 2004, 2008 and 2017, Di.Bi. received unsolicited orders from Turkey, but CD supposes that these were made only for copying purposes as some of their strongest competitors are Turkish. In 2019, she predicted: "We'll probably see our doors "Made in Turkey" in a few months."

In 2004, Di.Bi. also entered China. It hired a local agent and received orders from a large customer in 2005, 2006 and 2008. Since then Di.Bi. has invested in re-entry (in terms of technical requirements, certificates, a new agent, CD's visit), and this initially resulted in minor orders. Efforts continued with a new potential partner and they discussed establishing a Chinese-Italian joint venture in the future. Although in 2018, sales increased as Di.Bi. sold some samples, according to $\mathrm{CD}$, "they want a product with Chinese features, and we have very complicated problems related to developing this relationship: there is a very strong cultural barrier". Despite the problems, Di.Bi. found a new customer in 2020 and received orders for 233,000 EUR.

Single deliveries to Austria and Germany occurred in 2005. These markets are difficult for Di.Bi. as the customers prefer domestic suppliers and they have strict requirements for security doors. Despite challenges, Di.Bi. has investigated the possibility of re-entering Germany, and in 2018 it received an occasional order from Austria.

Strong local and regional competition was problematic for Di.Bi. in Central Europe. For example, in 2008, CD contacted a small customer in the Czech Republic but Di.Bi. only received a single order as it could not compete with lower-cost Polish competitors. Still, exports continued until 2014 as an Italian customer with a business in the region started buying Di.Bi.'s doors. In 2016, a new customer - a former export manager of an Italian firm producing internal doors (a Czech who returned home) - opened a showroom and started ordering. In 2018, sales increased as the customer got a large project but in 2019 , decreased considerably as that project ended.

Sometimes Di.Bi. entered new markets due to local activity. For example, in 2008, an Italian dealer living and working in France contacted Di.Bi. to import security doors. Two more dealers started ordering and CD found five new agents. She saw potential in France: "We are investing considerably because local manufacturers are only producing more expensive but lower quality security doors". To meet the market requirements, they have adapted their products (due to different installation systems), and they have invested in joining a French ordering system. Thus, CD hoped to achieve "strong increase" in the near future, and she achieved this in 2019 after finding some additional customers.

Opportunities also arose through network connections. For example, an agent from Nigeria who had previously been mainly specialized in shoes contacted Di.Bi. and ordered security doors as he hoped to expand his business. He got Di.Bi.'s contact through an Italian shoes producer. After filling a small order for his friend in 2008, this agent continued selling shoes, but later Di.Bi. found another Nigerian customer: an architect. Sales started in 2010 but fluctuated considerably depending on the architect's projects. In 2014, another Nigerian architect contacted Di.Bi. as in 2010 he had seen the firm's security doors in an Italian showroom. As Nigeria has considerable market potential, Di.Bi. is trying to expand its business there. In 2015, an agent specialized in ceramics was interested in selling security doors in Nigeria but no sales followed as this agent did not respond to CD's calls. In 2016, CD attended a trade fair in Nigeria together with a representative of another Italian security door producer and created 
several promising contacts. Sales increased considerably in 2017 as one of the architects needed high-quality doors for his new project. According to CD, "Nigeria has potential but doing business takes time and it's difficult to find serious business partners". In 2018, sales dropped but in 2019, Di.Bi. received two large orders, and sales increased again.

Besides having an agent or distributor, it is necessary for Di.Bi. to have an active export manager who keeps the markets "active". The agents and distributors need considerable support, and this was evident when CD was on maternity leave. Then, sales to some markets - including Tunisia entered in 2009 - stopped as "no-one travelled abroad". However, recently exports to Tunisia have increased as the customer's business has grown and as Di.Bi. has adjusted its products to local needs.

\section{The 2010s - Towards organized internationalization}

During this decade, Di.Bi.'s internationalization became institutionalized. It entered new markets annually but the export share seems to have reached a 'glass ceiling' - it never exceeded $30.1 \%$ of its turnover. In both 2017 and 2018, it was only $18.5 \%$ while in 2019 , it was $20.3 \%$.

Unsolicited orders led Di.Bi. to new markets (Australia, Belgium, British Virgin Islands, Cyprus, Egypt, Malta, Panama, San Marino, and United Arab Emirates) but usually without resulting in sustainable business. If the contact was made by the export manager (Denmark, Sweden), the result was the same. In Scandinavia, lack of demand resulted from customer taste differences, whereas in Libya, from unstable political situation.

Until 2019, trade fairs were important sources for contacts for Di.Bi.. ${ }^{9}$ In 2012, CD met a distributor from Saudi Arabia at an Italian trade fair, and in 2013, received the first order. In the same year, she attended a trade fair in Saudi Arabia and the distributor helped to create a contact with a local construction company. In 2015-2016, this was Di.Bi.'s largest export market. However, in 2017, the large project ended, and the distributor could not find other opportunities.

In 2013, Di.Bi. entered Ghana as an Italian windows producer helped to create a contact with a showroom owner. Di.Bi. received small orders in 2013-2014, but, thereafter, they stopped. CD started searching for new potential customers. In 2015, two Ghanaian agents visited Di.Bi. and CD visited them. In 2016, Di.Bi. sent samples to these agents and sold doors to a private person. After making several visits and spending considerable resources in the country, CD hoped to get 2-3 new orders. In 2018, Di.Bi. finally got one as its former customer's neighbours ordered.

CD has never been afraid of challenging markets. For example, in 2013, a security doors producer from Iran found Di.Bi.'s contacts through a website focused on construction materials. It wished to co-operate in producing Italian-style doors. In 2014, they participated together at a trade fair in Teheran, and the Iranian visited Di.Bi. and bought a sample. In 2015, CD visited Iran, and stated: "Negotiations have taken

\footnotetext{
${ }^{9}$ Their importance decreased for Di.Bi. as according to $\mathrm{CD}$, making sales after creating the initial contact sometimes takes too much time. For instance, they met an Algerian customer at a fair in May 2016 and finally managed to get an order in December 2018; in the meantime, the customer visited them two times and they met him three times. Still, in 2019 Di.Bi. attended a trade fair in Milan to meet "other interior door manufacturers to build relationships with complementary products producers".
} 
long; I hope to conclude a good contract next year". However, this distributor disappeared.

European markets can be also challenging. In 2014, CD formed a contact with a store-owner in London, $U K$ and received a small order. In 2015 she stated: "It is difficult to deal with the owner, especially because of cultural and character differences. For entering UK, we had to adapt our products, as their mailboxes are set into doors and they have different installation systems. Also, we will have to get an expensive British Standard certificate. We are ready to expand our presence; thus, we are analysing the market systematically to find local distributors and dealers, and we have also met a British designer. In addition, we have achieved an agreement with a distributor also selling our competitors' products and together, we will promote our products more widely in the UK." Despite considerable efforts, in 2016 sales stopped as the customer started ordering from a cheaper Spanish competitor (in 2018, Di.Bi. only received a small order for spare parts).

In 2014, an export agent created a contact with a construction company from Algeria. Moreover, CD met an Italian interior doors producer who created a contact with his customer who ordered interior doors in 2014. CD attended an Algerian trade fair in 2015 and received a large order from one of the most important Algerian construction companies. She sees some potential in Algeria "as their customers do not want Chinese products and they prefer high-quality Italian ones" but in 2016, Di.Bi.'s exports dropped considerably due to increased import tariffs. Moreover, according to $\mathrm{CD}$, bank transfers are very slow in Algeria, the market has become poorer, and the price level is too low for Di.Bi.. Still, in 2018 it found two new customers (one through a trade fair, the other through another Italian firm), and sales increased.

In 2015, CD attended a meeting (organized by an industry association) with a delegation from Senegal and created two interesting contacts. In 2015, Di.Bi. sold a few doors to one of them, while the other contact became Di.Bi.'s agent. In 2015, the junior export manager visited both active and potential Senegalese customers several times together with the agent. In the end of 2015, a dealer contacted the firm after visiting its website, asked for samples, and in 2017 made an order. Another dealer (with whom an Italian window producer created a contact) visited Di.Bi. in February 2016, but did not order anything.

In January 2016, Di.Bi. entered Colombia. It opened a showroom. It also tried to establish a sales subsidiary as an Italian emigrant living there (since 2015, the firm's agent) explained that this would improve Di.Bi.'s image. In 2015, the junior export manager visited Colombia several times and the Colombian agent visited Italy but he only sold three doors in 2016 and then disappeared. According to CD "it was a very bad experience, although we are still sure that Colombia has potential. After closing the showroom, we tried continuing in the market, but it is very difficult to visit Colombia every month: we need someone there. Some of our competitors are already present in Colombia but only through agents, they have never opened a showroom".

In 2017, Di.Bi. also entered Eritrea, but CD considers this experience a "nightmare": "Eritrea is the case of an Italian customer with a project abroad. The project was huge - in theory there were three other buildings - but the company delayed with payments". In 2018, sales ended as the project finished. In addition, through a Senegalese customer, Di.Bi. entered Gambia in 2017 but did not receive 
orders in 2018 or 2019. In 2018, Di.Bi. also entered Zambia through the same Senegalese customer.

In 2019, Di.Bi. entered Canada, Kuwait and Slovakia. In all three cases, a customer contacted the firm and made a small order. In spring 2020, Di.Bi.'s production was temporarily stopped due to the Covid-19 pandemic (sales activities continued via online channels) but it continued on 4th of May, 2020. According to $\mathrm{CD}$, she cannot yet assess how the pandemic could affect the firm's future export activities.

\section{Synthesis}

The case description highlights that Di.Bi.'s internationalization is characterized by continuous but unstable exports, and huge market-level fluctuations. Over the years, the firm has put a lot of effort in internationalization but still the commitment to most markets has remained low. It seems that experiential learning has been limited, as CD describes in the following quote: "There are more controllable countries, like France, where we have been working since 2009, and where we have had customers and agents and country feedback that is credible and can be monitored, and this has allowed us to make the right investments. It is difficult to invest to other countries where I don't have an equally long and positive history of experiences, especially as I don't have a person who is strong from a commercial point of view."

From the viewpoint of our research question, it is relevant to ask: what is entrepreneurial in Di.Bi.'s internationalization? If we consider every new product/market combination an entrepreneurial opportunity (in line with Mainela et al. 2014), then over the years Di.Bi. has recognized and exploited many opportunities, although sometimes unsuccessfully. The first international opportunities emerged in 1991, and since then, every year new opportunities have appeared. However, is this sufficient to label Di.Bi.'s behaviour fully entrepreneurial?

During the early years, Di.Bi. mainly exported via agents and local distributors. However, since 2008, it has had a dedicated person for exports, and later a junior export manager was recruited. ${ }^{10}$ The establishment of the export department can be labelled as an organizational innovation, and additional staff members brought in valued competences: language skills, knowledge of international business and customer relationships. Despite this, investments into internationalization have remained low compared to production or product development. This has been mainly because the founder-entrepreneur has not been fully committed to internationalization; his main interest lies in the production. ${ }^{11}$ When compared with its local competitors, CD considers Di.Bi. to be in a similar situation: commitment and investments to internationalization remain low, and therefore succeeding on international markets is challenging.

\footnotetext{
${ }^{10}$ In April 2018, his contract ended due to the owner's dissatisfaction with his performance, but in January 2020, he was replaced by a new person.

${ }^{11}$ This is also evident from Di.Bi.'s website: according to it, the firm's "pillars"are "high cutting-edge technology standards, ongoing innovation, care of aesthetics, customization of the product, care of ecosaving and fast production" (https:/www.dibigroup.com/en/who_we_are).
} 
$\mathrm{CD}$ has tried to negotiate the issue with the founder-entrepreneur (her father) but it has not been easy. For him it has been difficult to understand that foreign customers want changes in the product. His approach is straightforward: "I created the product, if you like it, buy it, if you don't like, then who cares". This means that overcoming change resistance regarding major product alterations takes time. For example, when CD explained to him that in some Eastern European markets the doors would need to be fire resistant for $30 \mathrm{~min}$, it took five years for him to accept that this was essential for selling the product there. A concrete example of how strong belief in the product does not always correlate with entrepreneurial behaviour.

Yet, in terms of technology, delivery and design Di.Bi. seems to be ahead of its competitors. Single actions can be considered proactive and risk-taking, such as opening a showroom in Colombia. Di.Bi.'s staff also carefully monitors the business environment, and gets lots of feedback, particularly from Italian customers. Price is an important buying criterion in the lower-price segment, and Di.Bi. either tries to follow its competitors' moves or to compete in higher-price segments. According to CD, "I don't necessarily need to sell a container of low-level doors, it's okay for me to do occasional sales of high-end doors. Through selling one luxury door I can earn as if I were selling 10 basic-type doors in terms of turnover, and the time spent on the transaction is the same."

As mentioned earlier, Di.Bi. has been rather bold in entering also less conventional, very turbulent markets. In that respect, it is a risk taker, but the risks have always been tolerable (see Johanson and Vahlne 1977) and the potential loss affordable (see Dew et al. 2009; Vissak et al. 2020). According to CD, most of internationalization-related decisions are made based on feelings and trust, not on structured and systematic risk assessment. Moreover, she explained: "Investment in online communication campaigns (through international online architecture portals) leads you to enter everyone's homes. These portals are cheap, are highly visible and have strong results, but this leads you to make many occasional sales". This again shows that for Di.Bi., occasional sales are normal, and risks associated with such sales are moderate. Moreover, conducting such sales takes less time than actively searching for customers via trade fairs and foreign market visits as these customers are actively searching for the products, thus they do not need to be convinced to buy (Hennart 2014).

To sum up, we may assess Di.Bi.'s international entrepreneurial proclivity (Zhou et al. 2010) in terms of innovativeness, proactiveness and risk-taking (Table 5). If innovativeness in considered as receptiveness of new ideas and ways, Di.Bi. is only moderately entrepreneurial. On the other hand, if proactiveness is investment in internationalization in the form of attending trade fairs, visiting customers, and searching for suppliers and customers, Di.Bi. is relatively proactive, although its investments are probably too thinly spread to make a major impact. Despite the firm's attempts to commit resources to more distant and/or volatile markets, $\mathrm{CD}$ also considers $\mathrm{Di}$.Bi. to be a risk-taker but on a tolerable level. Consequently, our illustrative case demonstrates that a firm may be entrepreneurial in some areas of its international activities, and less entrepreneurial in others: in other words, its internationalization can be "combined" in terms of its approach. 
Table 5 International entrepreneurial proclivity of $\mathrm{Di} . \mathrm{Bi}$

\begin{tabular}{|c|c|c|}
\hline Dimension & Our definition & Illustrative evidence \\
\hline Innovativeness & $\begin{array}{l}\text { receptiveness of new ideas and ways } \\
\text { to innovate }\end{array}$ & $\begin{array}{l}\text { "The scouting activity takes a lot of time.... in } 2018 \\
\text { another customer should start thanks to our } \\
\text { proactive scouting in } 2017 \text { in Romania." } \\
\text { "During the current year Di.Bi. has launched into } \\
\text { the market a new door which is fire resistant } \\
\text { according to the European certification .. French } \\
\text { market requires a fire rated certification for } \\
\text { security doors, so now Di.Bi. is able to better } \\
\text { penetrate the market with the new fire resistant } \\
\text { door." }\end{array}$ \\
\hline Proactiveness & $\begin{array}{l}\text { investment in internationalization, } \\
\text { actively searching for new } \\
\text { customers }\end{array}$ & $\begin{array}{l}\text { "We will attend the trade fair with two other Italian } \\
\text { manufacturers: one of windows and one of } \\
\text { internal doors, with which we are trying to build a } \\
\text { business network, for being more competitive than } \\
\text { competitors and for offering a wider range of } \\
\text { products." } \\
\text { "In the UK, in 2015, DBS visited both active and } \\
\text { potential customers in the country several times } \\
\text { as the firm sees potential in the market." } \\
\text { "We are investing a lot in the French market } \\
\text { because at the moment there are only French } \\
\text { manufacturers producing low quality security } \\
\text { doors with a higher price in comparison with our } \\
\text { price." }\end{array}$ \\
\hline Risk-taking & $\begin{array}{l}\text { mindset towards committing } \\
\text { resources to more distant and/or } \\
\text { volatile markets }\end{array}$ & $\begin{array}{l}\text { "We decided to open a sales subsidiary in Colombia. } \\
\text { We were contacted by an Italian emigrant living } \\
\text { here and working with architects, project } \\
\text { designers, etc. This person explained that in } \\
\text { Colombia it is necessary to have a subsidiary as a } \\
\text { matter of company's image, and also because a } \\
\text { subsidiary is a sign of safety and reliability." } \\
\text { "We would like to develop China as much as } \\
\text { possible and we are also evaluating the possibility } \\
\text { of a joint venture." }\end{array}$ \\
\hline
\end{tabular}

\section{Discussion and conclusions}

This research was set up to find out how SMEs combine entrepreneurial and nonentrepreneurial elements in their internationalization. Our case of an Italian industrial firm, Di.Bi., describes in detail the process over time. The study has links to earlier research both on SME internationalization and internationalization process of a firm.

Prior research has stressed the strategic aspect of internationalization. Already decades ago, Melin (1992) pointed out that internationalization is a strategy process, while more recently Hilmersson (2014) understood internationalization as a growth strategy which is followed to improve firm performance. However, we know that not all internationally operating SMEs are looking for growth 
(Nummela et al. 2005): the motivations for international expansion are much more diverse. For example, in our case firm they varied across generations: whereas for the founder (father), internationalization was needed for stability and survival, the daughter responsible for exports had higher international growth orientation. On the other hand, SMEs do not always follow a planned strategy but instead their internationalization is rather serendipitous (e.g., Crick and Crick 2014, Crick 2005). The internationalization of our case firm can also be described as a process of oscillation between serendipitous and planned actions (similar observations have been made before by Kiss et al. 2020, Vissak et al. 2020, Vissak and Francioni 2013). Furthermore, the case firm lacked a formal internationalization strategy, and its past international performance was not evaluated against pre-defined goals. ${ }^{12}$ This encourages us to propose:

\section{P1: Predominantly non-entrepreneurial internationalization can occur without developing a clearly defined internationalization strategy}

Our study also added to our understanding of the internationalization process. In line with Johanson and Vahlne (2009), we think that internationalization is a process of opportunity development which starts with opportunity recognition. However, in predominantly non-entrepreneurial internationalization, the firm does not strongly commit to a particular market (a clear deviation from, e.g., the Uppsala model developed by Johanson and Vahlne 1977) or to particular relationships or networks (Bembom and Schwens 2018; Johanson and Vahlne 2009). Di.Bi. seems to be committed to a continuous search of international markets but with its limited resources, its commitment does not result in considerable resource investment. Thus, the Uppsala model or other existing theories on the internationalization process of the firm seem to have a poor fit with our case, they need to be refined in order to capture also internationalization processes which include both entrepreneurial and non-entrepreneurial characteristics.

For example, the concept of experiential learning has been one of the core elements of internationalization literature since the 1970s (Johanson and Vahlne 1977). At first, it seems that the nonlinear internationalization of Di.Bi. has not led to any substantial learning within the firm. However, a closer look unveils that the learning in Di.Bi. has been more multifaceted than the traditional internationalization theories would indicate. It is true that Di.Bi.'s presence on several markets was so short that no deep market knowledge was obtained. ${ }^{13}$ In our case firm the main reason for this is that especially during its earlier internationalization, considerable sales came from indirect exports, so Di.Bi. lacked direct contacts with its customers. In these cases, agents and distributors filtered the market and customer information. Nevertheless, the negative experiences with some intermediaries led CD to state that Di.Bi.'s most important lesson has been: "Do not trust people any more, and above all intermediaries." In other words, instead of market knowledge, the firm obtained internationalization knowledge (Fletcher and Harris 2012). Additionally,

\footnotetext{
${ }^{12} \mathrm{CD}$ explained: "it is very difficult to make medium-term planning and understand what the trend will be".

13 This finding is similar to the study of Surdu et al. (2019) on multinational enterprises; they also found that experience does not always accumulate during internationalization.
} 


\begin{tabular}{|c|c|c|c|c|}
\hline & $\begin{array}{c}\text { attitudinal } \\
\text { barriers: e.g. } \\
\text { low risk-taking } \\
\text { due to } \\
\text { involvement of } \\
\text { more } \\
\text { conservative } \\
\text { and less export- } \\
\text { oriented family } \\
\text { members }\end{array}$ & & $\begin{array}{c}\text { lack of } \\
\text { capabilities } \\
\text { due to low } \\
\text { commitment to } \\
\text { most markets and } \\
\text { limited learning } \\
\text { opportunities } \\
\text { from previous } \\
\text { foreign activities }\end{array}$ & \\
\hline & & \multirow{3}{*}{$\begin{array}{l}\text { low commitment to } \\
\text { internationalization: } \\
\text { limited time and } \\
\text { financial resources } \\
\text { invested into } \\
\text { developing foreign } \\
\text { activities (overall and } \\
\text { on most markets) and } \\
\text { low product } \\
\text { adjustment readiness } \\
\text { due to attitudinal } \\
\text { barriers }\end{array}$} & I & \\
\hline $\begin{array}{l}\text { international } \\
\text { opportunity } \\
\text { development: } \\
\text { rather ad hoc and } \\
\text { unsystematic (e.g. } \\
\text { relying largely on }\end{array}$ & P3 & & $\begin{array}{r}1 \\
1 \\
1 \\
1 \\
1 \\
1 \\
1 \\
1\end{array}$ & \multirow{2}{*}{$\begin{array}{l}\text { nonlinear, mostly } \\
\text { non-entrepreneurial } \\
\text { internationalization: } \\
\text { multiple exits and re- } \\
\text { entries and a 'glass } \\
\text { ceiling' to export } \\
\text { share due to low } \\
\text { commitment, lack of } \\
\text { capabilities and } \\
\text { relying considerably } \\
\text { on unsolicited export } \\
\text { orders (P1, P2, P3) }\end{array}$} \\
\hline $\begin{array}{l}\text { unsolicited export } \\
\text { orders), not based } \\
\text { on a clearly } \\
\text { defined } \\
\text { internationalization } \\
\text { strategy } \\
\text { (P1) }\end{array}$ & i & & $\begin{array}{l}1 \\
1 \\
1 \\
1 \\
1 \\
1 \\
1 \\
1\end{array}$ & \\
\hline
\end{tabular}

P1: Predominantly non-entrepreneurial internationalization can occur without developing a clearly defined internationalization strategy.

P2: Low commitment to internationalization prevents capability development and leads to nonlinear internationalization.

P3: Family involvement may moderate international entrepreneurial orientation, possibly leading to more non-entrepreneurial internationalization.

Fig. 2 A conceptual framework

over the years, the firm has continued to persevere ${ }^{14}$ and consequently it has developed the resilience needed for serial nonlinear internationalization (Lafuente et al. 2018; Vissak et al. 2020).

Prior research on International Business often also ignores the role of the individual. Contrary to the mainstream literature, we stress the importance of the entrepreneur and the top management team. In fact, our case showed that SMEs' internationalization process considerably depends on their owners' and export managers' attitudes: if the former are not interested and dedicated enough, the latter will have problems due to lack of resources and customized products. In Di.Bi. the main barrier preventing a commitment increase is attitudinal: the founding entrepreneur is not motivated to invest in internationalization. Furthermore, non-entrepreneurial internationalization is characterized by lack of capabilities, and without commitment, the dynamic capabilities needed in internationalization cannot be developed (Vahlne and Johanson 2017). Therefore, routines are not formed and substantial learning does not occur. All this leads to a sporadic and nonlinear internationalization process (see Fig. 2). Consequently, we propose:

\footnotetext{
${ }^{14}$ Of the importance of perseverance in SMEs, see Baum and Locke (2004), Gerschewski et al. (2016) and Van Gelderen (2012).
} 
P2: Low commitment to internationalization prevents capability development and leads to nonlinear internationalization

Our critical case is very much a case of a family firm's international expansion (see, e.g., Metsola et al. 2020; Pukall and Calabrò 2014). In academic literature on the internationalization of family firms, the debate is very polarized. A restrictive view - family firms internationalize less than others - competes with a facilitative view: family firms internationalize more than others (Arregle et al. 2019). Our study also provides some support that family involvement ${ }^{15}$ affects entrepreneurial processes (Nordqvist and Melin 2010), and that its impact differs between the dimensions of entrepreneurial behaviour (Stenholm et al. 2016). High level of family involvement supports innovativeness but affects negatively proactiveness and risk-taking (Casillas and Moreno 2010) - this was also evident in our case. The case also supports the finding that the second generation is more inclined towards internationalization than the first one (Merino et al. 2015). Family involvement may also be a significant factor in explaining the 'glass ceiling' in terms of a firm's international entrepreneurial orientation (Pukall and Calabrò 2014), especially if it is specialized in massmarket goods, not global niche products (Hennart et al. 2019). Therefore, we propose the following:

\section{P3: Family involvement may moderate international entrepreneurial orientation, possibly leading to more non-entrepreneurial internationalization.}

As any study, this one has some limitations. Perceptions of entrepreneurship and entrepreneurial behaviour vary across national cultures. Therefore, although we do not perceive Di.Bi.'s behaviour fully entrepreneurial but rather "combined" with predominantly non-entrepreneurial characteristics, their own interpretation may differ (see, e.g., Randerson 2016). Furthermore, entrepreneurial orientation focuses on firm behaviour in a given industry (Lumpkin and Dess 1996), and what is deemed entrepreneurial in one industry, might not be considered so in another. We would also like to highlight the context of the study. Earlier research points out that the role of family involvement is particularly strong in Italy (Cucculelli et al. 2014), something which may be reflected in our illustrative case. However, our case study was not aimed to be a representative but an illustrative one: it helped us to understand how and why internationalizing SMEs combine entrepreneurial and non-entrepreneurial behaviour.

We hope to see more studies which acknowledge that all SMEs' internationalization is not fully entrepreneurial. For instance, it would be interesting to find out if other family- and non-family-owned small internationalizers' experiences have been (dis)similar: how (non-) entrepreneurial they have been in their internationalization and which factors have affected their entries, exits and reentries. This would also allow developing detailed managerial and policy implications.

\footnotetext{
${ }^{15}$ Family involvement is defined as the degree to which family members control the firm and are involved in its strategic and operational management (Calabrò et al. 2017; Casillas and Moreno 2010; Hennart et al. 2019).
} 
Acknowledgements This work was supported by the Institutional Research Funding IUT20-49 of the Estonian Ministry of Education and Research and by the Estonian Research Council's grant PUT 1003.

\section{Appendix}

Table 6 Di.Bi.'s case profile

$\begin{array}{ll}\text { Website } & \text { http://www.dibigroup.com/en/ } \\ \text { Foundation year } & 1976 \\ \text { Location } & \text { Fano, Italy } \\ \text { Key decision-makers } & \text { Michele Delvecchio (CEO and owner; founded Di.Bi. when he was 22) } \\ & \text { Elisabetta Maggiori (wife, joined Di.Bi. in 1979; responsible for accounting, } \\ \text { finance and purchasing) } \\ \text { Caterina Delvecchio (daughter, joined Di.Bi. in 2008; responsible for exports, } \\ \text { marketing and public relations) } \\ \text { Cesare Delvecchio (son, joined Di.Bi. in 2008; responsible for production and } \\ \text { R\&D) }\end{array}$

Involvement of other family The owner's sister-in-law is working part-time in administration. The owner's members brother supervised one of the production departments for more than 20 years but retired.

Turnover

3.4 million EUR in 2019 (export turnover: 0.69 million EUR)

Number of employees

40 in 2020 (4 in 1976)

Main activities

In the beginning, it was a sub-contractor doing artisanal ironwork for other companies. Di.Bi. started producing security doors in 1981 as the entrepreneur had created contacts with customers who asked him to produce them. Thus, he bought a door, dismantled and reassembled it and, thereafter, decided to specialize in them. In 1994, Di.Bi. also started producing security shutters for windows, in 2004, finishing panels for doors, in 2007, interior doors, in 2014, luxury doors and in 2016, fire resistant doors. It has used various materials and co-operated with designers to turn their products into design elements.

Internationalization

Due to home market turbulence and the need to spread risks, started in 1991 from exporting to Bulgaria; in 2019, Di.Bi. exported to 24 countries and had an export share of $20.3 \%$ (see Table 1)

\section{References}

Acedo, F. J., \& Galán, J. L. (2011). Export stimuli revisited: The influence of the characteristics of managerial decision makers on international behaviour. International Small Business Journal, 29(6), 648-670.

Alayo, M., Maseda, A., Iturralde, T., \& Arzubiaga, U. (2019). Internationalization and entrepreneurial orientation of family SMEs: The influence of the family character. International Business Review, $28(1), 48-59$.

Amorós, J. E., Basco, R., \& Romaní, G. (2016). Determinants of early internationalization of new firms: The case of Chile. International Entrepreneurship and Management Journal, 12(1), 283-307.

Andresen, M., \& Bergdolt, F. (2017). A systematic literature review on the definitions of global mindset and cultural intelligence - Merging two different research streams. International Journal of Human Resource Management, 28(1), 170-195. 
Arregle, J. L., Duran, P., Hitt, M. A., \& van Essen, M. (2017). Why is family firms' internationalization unique? A meta-analysis. Entrepreneurship: Theory and Practice, 41(5), 801-831.

Arregle, J. L., Hitt, M. A., \& Mari, I. (2019). A missing link in family firms' internationalization research: Family structures. Journal of International Business Studies, 50(5), 809-825.

Autio, E. (2017). Strategic entrepreneurial internationalization: A normative framework. Strategic Entrepreneurship Journal, 11(3), 211-227.

Baier-Fuentes, H., Merigó, J. M., Amorós, J. E., \& Gaviria-Marín, M. (2019). International entrepreneurship: A bibliometric overview. International Entrepreneurship and Management Journal, 15(2), 385-429.

Balabanis, G., \& Spyropoulou, S. (2007). Matching modes of export strategy development to different environmental conditions. British Journal of Management, 18(1), 45-62.

Baum, J. R., \& Locke, E. A. (2004). The relationship of entrepreneurial traits, skill, and motivation to subsequent venture growth. Journal of Applied Psychology, 89(4), 587-598.

Bell, J., McNaughton, R., \& Young, S. (2001). Born-again global firms - An extension to the 'born global' phenomenon. Journal of International Management, 7(3), 173-189.

Bembom, M., \& Schwens, C. (2018). The role of networks in early internationalizing firms: A systematic review and future research agenda. European Management Journal, 36(6), 679-694.

Bernini, M., Du, J., \& Love, J. (2016). Explaining intermittent exporting: Exit and conditional re-entry in export markets. Journal of International Business Studies, 47(9), 1058-1076.

Buckley, P. J., \& Casson, M. C. (1976). The future of the multinational enterprise. London: Macmillan.

Buckley, P. J., \& Casson, M. C. (1998). Analyzing foreign market entry strategies: Extending the internalization approach. Journal of International Business Studies, 29(3), 539-561.

Buckley, P. J., \& Casson, M. (2020). The internalization theory of the multinational enterprise: Past, present and future. British Journal of Management, 31(2), 239-252.

Calabrò, A., Campopiano, G., Basco, R., \& Pukall, T. (2017). Governance structure and internationalization of family-controlled firms: The mediating role of international entrepreneurial orientation. European Management Journal, 35(2), 238-248.

Casillas, J. C., \& Moreno, A. M. (2010). The relationship between entrepreneurial orientation and growth: The moderating role of family involvement. Entrepreneurship \& Regional Development, 22(3-4), 265-291.

Christmann, H., Alexander, A., \& Wood, S. (2016). Exploring brand identity and entrepreneurship as drivers of small specialist retailer internationalisation: A German case study. International Review of Retail, Distribution and Consumer Research, 26(2), 137-153.

Ciravegna, L., Kundu, S. K., Kuivalainen, O., \& Lopez, L. E. (2019). The timing of internationalization Drivers and outcomes. Journal of Business Research, 105, 322-332.

Covin, J., \& Slevin, D. (1988). The influence of organization structure on the utility of an entrepreneurial top management style. Journal of Management Studies, 25(3), 217-234.

Crick, D., \& Crick, J. (2014). The internationalization strategies of rapidly internationalizing high-tech UK SMEs: Planned and unplanned activities. European Business Review, 26(5), 421-448.

Crick, D., \& Spence, M. (2005). The internationalisation of 'high performing' UK high-tech SMEs: A study of planned and unplanned strategies. International Business Review, 14(2), 167-185.

Cucculelli, M., Mannarino, L., Pupo, V., \& Ricotta, F. (2014). Owner-management, firm age, and productivity in Italian family firms. Journal of Small Business Management, 52(2), 325-343.

De Clercq, D., Sapienza, H. J., \& Crijns, H. (2005). The internationalization of small and medium-sized firms. Small Business Economics, 24(4), 409-419.

De Massis, A., \& Kotlar, J. (2014). The case study method in family business research: Guidelines for qualitative scholarship. Journal of Family Business Strategy, 5(1), 15-29.

Debicki, B. J., Kellermanns, F. W., Chrisman, J. J., Pearson, A. W., \& Spencer, B. A. (2016). Development of a socioemotional wealth importance (SEWi) scale for family firm research. Journal of Family Business Strategy, 7(1), 47-57.

Dess, G. G., Lumpkin, G. T., \& Covin, J. G. (1997). Entrepreneurial strategy making and firm performance: Tests of contingency and configurational models. Strategic Management Journal, 18(9), 677-695.

Dew, N., Read, S., Sarasvathy, S. D., \& Wiltbank, R. (2009). Effectual versus predictive logics in entrepreneurial decision-making: Differences between experts and novices. Journal of Business Venturing, 24(4), 287-309.

Dubois, A., \& Gadde, L. E. (2002). Systematic combining: An abductive approach to case research. Journal of Business Research, 55(7), 553-560.

Dunning, J. H. (1973). The determinants of international production. Oxford Economic Papers, 25(3), 289336. 
Dunning, J. H. (1977). Trade, location and economic activity and the multinational enterprise: A search for an eclectic approach. In B. Ohlin, P. Hesselborn, \& M. Wijkman (Eds.), The international allocation of economic activity (pp. 395-418). New York: Holmes \& Meier.

Dunning, J. H. (2000). The eclectic paradigm as an envelope for economic and business theories of MNE activity. International Business Review, 9(2), 163-190.

Dyer Jr., W. G., \& Wilkins, A. L. (1991). Better stories, not better constructs, to generate better theory: A rejoinder to Eisenhardt. Academy of Management Review, 16(3), 613-619.

Dzikowski, P. (2018). A bibliometric analysis of born global firms. Journal of Business Research, 85, 281294.

Easton, G. (2010). Critical realism in case study research. Industrial Marketing Management, 39(1), 118-128.

Eisenhardt, K. M. (1989). Building theories from case study research. Academy of Management Review, 14(4), 532-550.

Etemad, H. (2018). The essence of entrepreneurial internationalization: Managing the dynamic complexity of interactive relationship and reflective adaptations. Journal of International Entrepreneurship, 16(3), 325337.

Fletcher, M., \& Harris, S. (2012). Knowledge acquisition for the internationalization of the smaller firm: Content and sources. International Business Review, 21(4), 631-647.

Fletcher, M., \& Plakoyiannaki, E. (2011). Case selection in international business: Key issues and common misconceptions. In R. Piekkari \& C. Welch (Eds.), Rethinking the case study in international business and management research (pp. 171-191). Cheltenham: Edward Elgar.

Francioni, B., Musso, F., \& Vardiabasis, D. (2013). Key decisions and changes in internationalization strategies: The case of smaller firms. Journal of Strategic Marketing, 21(3), 240-259.

Geertz, C. (1973). The interpretation of cultures: Selected essays. New York: Basic Books.

Gerschewski, S., Lindsay, V. J., \& Rose, E. (2016). Advancing the entrepreneurial orientation construct: The role of passion and perseverance. Review of International Business and Strategy, 26(4), 446-471.

Hagen, B., Zucchella, A., \& Ghauri, P. N. (2019). From fragile to agile: Marketing as a key driver of entrepreneurial internationalization. International Marketing Review, 36(2), 260-288.

Helfat, C. E. (2007). Stylized facts, empirical research and theory development in management. Strategic Organization, 5(2), 185-192.

Hennart, J. F. (2014). The accidental internationalists: A theory of born globals. Entrepreneurship Theory and Practice, 38(1), 117-135.

Hennart, J. F., Majocchi, A., \& Forlani, E. (2019). The myth of the stay-at-home family firm: How familymanaged SMEs can overcome their internationalization limitations. Journal of International Business Studies, 50(5), 758-782.

Hilmersson, M. (2014). Small and medium-sized enterprise internationalisation strategy and performance in times of market turbulence. International Small Business Journal, 32(4), 386-400.

Hurmerinta-Peltomäki, L. (2003). Time and internationalisation. Theoretical challenges set by rapid internationalization. Journal of International Entrepreneurship, 1(2), 217-236.

Jantunen, A., Nummela, N., Puumalainen, K., \& Saarenketo, S. (2008). Strategic orientations of born globals - Do they really matter? Journal of World Business, 43(2), 158-170.

Järvensivu, T., \& Törnroos, J. A. (2010). Case study research with moderate constructionism: Conceptualization and practical illustration. Industrial Marketing Management, 39(1), 100-108.

Jin, B., Jung, S., \& Jeong, S. W. (2018). Dimensional effects of Korean SME's entrepreneurial orientation on internationalization and performance: The mediating role of marketing capability. International Entrepreneurship and Management Journal, 14(1), 195-215.

Johanson, J., \& Vahlne, J. E. (1977). The international process of the firm: A model of knowledge development and increasing foreign market commitments. Journal of International Business Studies, $8(1), 23-32$.

Johanson, J., \& Vahlne, J. E. (2009). The Uppsala internationalization process model revisited: From liability of foreignness to liability of outsidership. Journal of International Business Studies, 40(9), 1411-1431.

Jones, M. V., \& Coviello, N. E. (2005). Internationalisation: Conceptualising an entrepreneurial process of behaviour in time. Journal of International Business Studies, 36(3), 284-303.

Jones, M. V., Coviello, N., \& Tang, Y. K. (2011). International entrepreneurship research (1989-2009): A domain ontology and thematic analysis. Journal of Business Venturing, 26(6), 632-659.

Kahiya, E. T. (2020). Context in international business: Entrepreneurial internationalization from a distant small open economy. International Business Review, 29(1), 101621.

Kiss, A. N., Danis, W. M., Nair, S., \& Suddaby, R. (2020). Accidental tourists? A cognitive exploration of serendipitous internationalisation. International Small Business Journal, 38(2), 65-89. 
Knight, G. A., \& Cavusgil, S. T. (1996). The born global firm: A challenge to traditional internationalization theory. In S. T. Cavusgil \& T. Madsen (Eds.), Advances in international marketing, 8 (pp. 11-26). Greenwich, CT: JAI Press.

Kuivalainen, O., Saarenketo, S., \& Puumalainen, K. (2012). Start-up patterns of internationalization: A framework and its application in the context of knowledge-intensive SMEs. European Management Journal, 30(4), 372-385.

Kutschker, M., Bäurle, I., \& Schmid, S. (1997). International evolution, international episodes, and international epochs: Implications for managing internationalization. Management International Review, 37(SI2), 101-124.

Lafuente, E., Vaillant, Y., Vendrell-Herrero, F., \& Gomes, E. (2018). Bouncing back from failure: Entrepreneurial resilience and the internationalisation of subsequent ventures created by serial entrepreneurs. Applied Psychology, 68(4), 658-694.

Langley, A. (1999). Strategies for theorizing from process data. Academy of Management Review, 24(4), 691710 .

Lazaris, M., Ngasri, N. E. M., \& Freeman, S. (2015). Reactive and proactive international entrepreneurial behaviour: Causation and effectuation. In P. N. Ghauri \& V. H. M. Kirpalani (Eds.), Handbook of research on international entrepreneurship strategy: Improving SME performance globally (pp. 22-44). Cheltenham: Edward Elgar.

Leonard-Barton, D. (1990). A dual methodology for case studies: Synergistic use of a longitudinal single site with replicated multiple sites. Organization Science, 1(3), 248-266.

Llanos-Contreras, O., Jabri, M., \& Sharma, P. (2019). Temporality and the role of shocks in explaining changes in socioemotional wealth and entrepreneurial orientation of small and medium family enterprises. International Entrepreneurship and Management Journal, 15(4), 1269-1289.

Lloyd-Reason, L., \& Mughan, T. (2002). Strategies for internationalisation within SMEs: The key role of the owner-manager. Journal of Small Business and Enterprise Development, 9(2), 120-129.

Love, J. H., \& Ganotakis, P. (2013). Learning by exporting: Lessons from high-technology SMEs. International Business Review, 22(1), 1-17.

Lu, J. W., \& Beamish, P. W. (2001). The internationalization and performance of SMEs. Strategic Management Journal, 22(6/7), 565-588.

Lumpkin, G. T., \& Dess, G. G. (1996). Clarifying the entrepreneurial orientation construct and linking it to performance. Academy of Management Review, 21(1), 135-172.

Magnani, G., \& Zucchella, A. (2019). Coping with uncertainty in the internationalisation strategy: An exploratory study on entrepreneurial firms. International Marketing Review, 36(1), 131-163.

Mainela, T., Puhakka, V., \& Servais, P. (2014). The concept of international opportunity in international entrepreneurship: A review and a research agenda. International Journal of Management Reviews, 16(1), $105-129$.

Melin, L. (1992). Internationalization as a strategy process. Strategic Management Journal, 13(S2), 99-118.

Merino, F., Monreal-Pérez, J., \& Sánchez-Marín, G. (2015). Family SMEs' internationalization: Disentangling the influence of familiness on Spanish firms' export activity. Journal of Small Business Management, 53(4), 1164-1184.

Metsola, J., Leppäaho, T., Paavilainen-Mäntymäki, E., \& Plakoyiannaki, E. (2020). Process in family business internationalisation: The state of the art and ways forward. International Business Review, 29(2), 101665.

Morais, F., \& Ferreira, J. J. (2020). SME internationalisation process: Key issues and contributions, existing gaps and the future research agenda. European Management Journal, 38(1), 62-77.

Nordqvist, M., \& Melin, L. (2010). Entrepreneurial families and family firms. Entrepreneurship and Regional Development, 22(3-4), 211-239.

Nummela, N., Puumalainen, K., \& Saarenketo, S. (2005). International growth orientation of knowledgeintensive small firms. Journal of International Entrepreneurship, 3(1), 5-18.

O'Cass, A., \& Weerawardena, J. (2009). Examining the role of international entrepreneurship, innovation and international market performance in SME internationalization. European Journal of Marketing, 43(11/ 12), 1325-1348.

Oviatt, B. M., \& McDougall, P. P. (1994). Toward a theory of international new ventures. Journal of International Business Studies, 25(1), 45-64.

Oviatt, B. M., \& McDougall, P. P. (2005). Defining international entrepreneurship and modeling the speed of internationalization. Entrepreneurship Theory \& Practice, 29(5), 537-553.

Øyna, S., \& Alon, I. (2018). A review of born globals. International Studies of Management and Organization, 48(2), 157-180.

Pascucci, F., \& Bartoloni, S. (2018). Explaining the internationalisation pathways of family firms: A qualitative research. International Journal of Business and Globalisation, 20(4), 537-556. 
Patton, M. Q. (2015). Qualitative research \& evaluation methods: Integrating theory and practice. Thousand Oaks: Sage.

Piekkari, R., Welch, C., \& Paavilainen, E. (2009). The case study as disciplinary convention: Evidence from international business journals. Organizational Research Methods, 12(3), 567-589.

Pukall, T. J., \& Calabrò, A. (2014). The internationalization of family firms: A critical review and integrative model. Family Business Review, 27(2), 103-125.

Randerson, K. (2016). Entrepreneurial orientation: Do we actually know as much as we think we do? Entrepreneurship \& Regional Development, 28(7-8), 580-600.

Reuber, A. R., Dimitratos, P., \& Kuivalainen, O. (2017). Beyond categorization: New directions for theory development about entrepreneurial internationalization. Journal of International Business Studies, 48(4), $411-422$.

Rialp-Criado, A., Galván-Sánchez, I., \& Suárez-Ortega, S. M. (2010). A configuration-holistic approach to born-global firms' strategy formation process. European Management Journal, 28(2), 108-123.

Romanello, R., \& Chiarvesio, M. (2019). Early internationalizing firms: 2004-2018. Journal of International Entrepreneurship, 17(2), 172-219.

Rugman, A. M., \& Verbeke, A. (2003). Extending the theory of the multinational enterprise: Internalization and strategic management perspectives. Journal of International Business Studies, 34(2), 125-137.

Santangelo, G. D., \& Meyer, K. E. (2017). Internationalization as an evolutionary process. Journal of International Business Studies, 48(9), 1114-1130.

Sedziniauskiene, R., Sekliuckiene, J., \& Zucchella, A. (2019). Networks' impact on the entrepreneurial internationalization: A literature review and research agenda. Management International Review, 59(5), 779-823.

Siggelkow, N. (2007). Persuasion with case studies. Academy of Management Journal, 50(1), $20-24$.

Slevin, D. P., \& Terjesen, S. A. (2011). Entrepreneurial orientation: Reviewing three papers and implications for further theoretical and methodological development. Entrepreneurship: Theory \& Practice, 35(5), 973-987.

Stenholm, P., Pukkinen, T., \& Heinonen, J. (2016). Firm growth in family businesses - The role of entrepreneurial orientation and the entrepreneurial activity. Journal of Small Business Management, 54(2), 697713.

Sundqvist, S., Kyläheiko, K., Kuivalainen, O., \& Cadogan, J. W. (2012). Kirznerian and Schumpeterian entrepreneurial-oriented behavior in turbulent export markets. International Marketing Review, 29(2), 203-219.

Surdu, I., Mellahi, K., \& Glaister, K. W. (2019). Once bitten, not necessarily shy? Determinants of foreign market re-entry commitment strategies. Journal of International Business Studies, 50(3), 393-422.

Tabares, A., Chandra, Y., Alvarez, C., \& Escobar-Sierra, M. (2020). Opportunity-related behaviors in international entrepreneurship research: A multilevel analysis of antecedents, processes, and outcomes. International Entrepreneurship and Management Journal in press. https://doi.org/10.1007/s11365-02000636-3.

Tang, Z., Kreiser, P. M., Marino, L., Dickson, P., \& Weaver, K. M. (2009). A hierarchical perspective of the dimensions of entrepreneurial orientation. International Entrepreneurship and Management Journal, 5(2), 181-201.

Tiessen, J. H., \& Merrilees, B. (1999). An entrepreneurial model of SME internationalization. Evidence from six cases. In R. W. Wright (Ed.), Research in global strategic management, 7 (pp. 131-154). Bingley: Emerald.

Torkkeli, L., Nummela, N., \& Saarenketo, S. (2018). A global mindset - Still a prerequisite for successful SME internationalization? In N. Dominguez \& U. Mayrhofer (Eds.), Key success factors of SME internationalisation: A cross-country perspective (pp. 7-24). Bingley: Emerald.

Torkkeli, L., Kuivalainen, O., Saarenketo, S., \& Puumalainen, K. (2019). Institutional environment and network competence in successful SME internationalisation. International Marketing Review, 36(1), 31-55.

Tsang, E. W. (2014). Generalizing from research findings: The merits of case studies. International Journal of Management Reviews, 16(4), 369-383.

Vahlne, J. E., \& Johanson, J. (2017). From internationalization to evolution: The Uppsala model at 40 years. Journal of International Business Studies, 48(9), 1087-1102.

Van Gelderen, M. (2012). Perseverance strategies of enterprising individuals. International Journal of Entrepreneurial Behaviour \& Research, 18(6), 630-648.

Verbeke, A., \& Ciravegna, L. (2018). International entrepreneurship research versus international business research: A false dichotomy? Journal of International Business Studies, 49(4), 387-394. 
Vissak, T., \& Francioni, B. (2013). Serial nonlinear internationalization in practice: A case study. International Business Review, 22(6), 951-962.

Vissak, T., \& Masso, J. (2015). Export patterns: Typology development and application to Estonian data. International Business Review, 24(4), 652-664.

Vissak, T., Francioni, B., \& Freeman, S. (2020). Foreign market entries, exits and re-entries: The role of knowledge, network relationships and decision-making logic. International Business Review, 29(1), 101592.

Welch, L. S. (2004). International entrepreneurship and internationalization: Common threads. In L. P. Dana (Ed.), Handbook of research on international entrepreneurship (pp. 137-149). Cheltenham: Edward Elgar.

Welch, C., Piekkari, R., Plakoyiannaki, E., \& Paavilainen-Mäntymäki, E. (2011). Theorising from case studies: Towards a pluralist future for international business research. Journal of International Business Studies, 42(5), 740-762.

Zahra, S. A., Korri, J. S., \& Yu, J. (2005). Cognition and international entrepreneurship: Implications for research on international opportunity recognition and exploitation. International Business Review, 14(2), 129-146.

Zhou, L., Barnes, B. R., \& Lu, Y. (2010). Entrepreneurial proclivity, capability upgrading and performance advantage of newness among international new ventures. Journal of International Business Studies, 41(5), 882-905.

Publisher's note Springer Nature remains neutral with regard to jurisdictional claims in published maps and institutional affiliations.

\section{Affiliations}

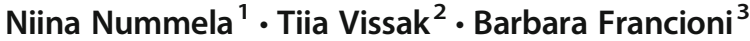

1 Turku School of Economics, University of Turku, Rehtorinpellonkatu 3, 20500 Turku, Finland

2 School of Economics and Business Administration, University of Tartu, Narva Rd. 18-4031, 51009 Tartu, Estonia

3 Department of Communication Sciences, Humanities and International Studies, Cultures, Languages, Literatures, Arts, Media (DISCUI), University of Urbino Carlo Bo, Via Saffi, 15, 61029 Urbino, Italy 